\title{
The Effects of Exchange Rate Volatility on ASEAN-China Bilateral Exports
}

\author{
Mohammed B. Yusoff and Ahmed Hossain Sabit
}

\begin{abstract}
The paper examines the impact of exchange rate volatility, real GDP of China, and real exchange rates on the bilateral exports of ASEAN member countries to China using the generalized method of moments. The results show that all the coefficients of these variables have the expected signs and are statistically significant. Specifically, if exchange rate volatility goes up by 1 percent, the exports fall by about 0.21 percent; if real exchange rate depreciates by 1 percent, exports will increase by 1.12 percent, and when China's real GDP increases by 1 percent, the ASEAN exports to China increase by 1.86 percent. The findings suggest that the ASEAN member nations should maintain the stability of their bilateral exchange rates with Chinese Yuan as a means to boost their exports to China.
\end{abstract}

Index Terms-Bilateral exports, exchange rate volatility, ASEAN-China.

\section{INTRODUCTION}

It has been argued that the rapid increase in exchange rate volatility following the collapse of Bretton-Woods system in 1971, has had significant adverse effects on international trade, especially on emerging economies with underdeveloped capital markets and unstable economic policies, Prasad, Rogoff, Wei \& Kose [1]. One of the criticisms of flexible exchange rate regime is that it increases the level of exchange rate uncertainty which reduces the incentives to trade. There have been a number of studies focusing on the impacts of exchange rate volatility on trade. But the causal link between exchange rate volatility and exports is still inconclusive. Cho \& McCorriston [2] show that the long-run changes in exchange rates seem to have more significant impacts on trade volumes than in short-run, as short-run exchange rate fluctuations can be hedged at low cost. But Krugman [3] argues that hedging is costly and imperfect. On the other hand, Vianne \& de Vires [4] show that short-run exchange rate volatility still affects trade because it may increase the risk premium in the forward exchange rate.

Exports can influence the level of economic growth, employment and the balance of payments of a country since fluctuations in export earnings introduce uncertainties in an economy and these uncertainties may adversely affect the efficiency of investment, which in turn, have a negative effect on growth. Exchange rate is one of the major determinants of the level of exports as it determines international competitiveness of a country. But the volatility in the

Manuscript received November 5, 2013; revised January 8, 2014.

Mohammed B. Yusoff is with the International Islamic University, Malaysia (e-mail: mohammed.yusoff@iium.edu.my).

Ahmed Hossain Sabit is with the Texas Tech University, Texas, USA (e-mail: sabit006@gmail.com). exchange rate can make a country less competitive in the international market and these negative effects of the exchange-rate volatility on trade are found to be more pronounced for developing countries, Grier \& Smallwood [5] and Aghion \& Howitt [6].

ASEAN and China have been experiencing ever growing trade relations in the last three decades. With the exception of Singapore, all of these countries are still considered as developing countries. Hence, the main objective of this study is to examine the impacts of exchange rate volatility in determining the direction of bilateral exports among ASEAN member nations to China. The specific objectives of this study are: to analyze the trade relations between ASEAN and China; to examine the effect of exchange rate volatility on ASEAN exports to China; and to assist policy makers in the formulation of effective exchange rate policy to stabilize the level of exchange rate volatility and help improve the performance ASEAN exports to China.

Trade and economic ties between ASEAN and China have been growing rapidly over the past years, especially after the signing of the Framework Agreement on Comprehensive Economic Cooperation in November 2002 to establish the ASEAN-China Free Trade Agreement (ACFTA). The China-ASEAN Free Trade Area (CAFTA) marks another milestone in the ASEAN-China relations. Prior to the realization of ACFTA on 1 January 2010, Trade in Goods Agreement, Trade in Service Agreement and the Investment Agreement under the Framework Agreement of Comprehensive Economic Cooperation were concluded and signed on 29 November 2004, 14 January 2007 and 15 August 2009, respectively. The ACFTA was realized on 1 January 2010 as almost 97 per cent of products classified by ASEAN-6 (Brunei Darussalam, Indonesia, Malaysia, the Philippines, Singapore and Thailand) and China in the Normal Track have been eliminated. The transition ASEAN member consisting of Canbodia, Laos, Myanmar, and Vietnam (CLMV) will fully implement the ACFTA on 1 January 2015.

Mutual investment has also expanded. From 1991-2000, ASEAN investment in China increased at an annual average rate of 28\%. In 1991, ASEAN investment in China was only US $\$ 90$ million which increased to US $\$ 26.2$ billion by 2001 , accounting for $7.7 \%$ of China's overseas investments. According to ASEAN statistics, the net FDI inflow from China to ASEAN in 2009, 2010 and 2011 were US\$1.85, US $\$ 2.78$ and US $\$ 6.03$ billion US dollar respectively. China has become the ASEAN's largest trading partner since 2009. Trade between ASEAN and China increased by $20.9 \%$ from US \$232 billion in 2010 to US \$280.4 billion in 2011. In 2011 ASEAN exports to China was at US $\$ 145.7$ billion, an increase of $28.9 \%$ compared to the previous year while 
ASEAN imports from China grew by $13.2 \%$ amounting to US $\$ 134.7$ billion, giving the trade surplus to ASEAN for the first time in 2011, with exports exceeding imports by US $\$ 11$ billion.

\section{LITERATURE REVIEW}

The nexus between exports and exchange rate volatility has been investigated widely by a number of scholars. The theoretical literature has introduced different models to determine whether there exists a significant impact of exchange rate volatility on export volume.

The partial equilibrium model for risk-averse firms suggests a negative relation between exchange rate volatility and trade. The assumptions are that these firms are constrained to exchange rate risk and hedging is not possible or costly, Clark [7], Ethier [8], and Kawai \& Zilcha [9]. This theoretical model is applicable for most developing countries where financial market is relatively less developed. In this situation, exchange rate plays a dominant role in determining the level of profits. If a firm is risk averse in nature then high volatility in exchange rate will definitely reduce its amount of its exports. This is because firms of this nature try to maximize its expected utility of profit and minimize the potential risk.

Prediction of the partial equilibrium model is basically based on a specific form of utility function. The assumptions of this model are quite restrictive in nature, De Grauwe [10]. The problem with these assumptions is that when restrictions are relaxed then the sign of the effect becomes ambiguous, even if we maintain the assumption of risk aversion. De Grauwe [10] has pointed out an important aspect of change in the level of risk. He argues that the effect of an increase in risk can be decomposed into substitution effect and income effect. Due to an increase in exchange rate risk, a risk adverse firm will shift its business to a less risky venture from more risky export activities, which is substitution effect. The income effect is a situation where an increase in exchange rate risk induces a shift of resources into the export sector. The income effect induces a shift of resources into the export sector when expected utility of export revenues declines as a result of the increase in exchange rate risk. Hence, if the income effect dominates the substitution effect, exchange rate volatility will have a positive impact on export activity. So, the ultimate effect of exchange rate volatility depends on the magnitude of these two effects.

A firm can also benefit from the exchange rate volatility depending it ability to hedge the exchange rate risk and its capacity to adjust the volume of exports to the exchange rate movement. Some studies concluded that the exchange rate volatility can increase the value of the firm which ultimately promotes export activities. Franke [11] and Sercu \&Van Hulle [12] show that an increase in exchange rate risk can increase the value of exporting firms and thus can accelerate economic activities if the firms have the ability to respond to the price changes.

Most empirical studies in 1980s and 1990s using time series data did not find negative significant effect of exchange-rate volatility on aggregate trade volumes. But many recent studies, using panel data and more sophisticated econometric techniques, find evidences of negative significant effects. Bailey \& Tavlas [13] and Holly [14] using time series data of industrialized countries find no negative impact of exchange rate volatility on exports. But De Grauwe [10] and Bini-Smaghi [15] (1991) find significant negative effect although they also used time series data of industrialized countries. Other studies used cross-section data, such as Brada \& Mendez [16] and Frankel \& Wei [17] and find negative impact of exchange rate volatility on trade volume, albeit relatively small.

Evidences from developing nations are also in line with the hypothesis that the exchange rate volatility has a negative impact on trade volume. Arize, Osang \& Slottje [18] and Dognalar [19] find negative impact of exchange rate risk on export volume. But almost none of these studies focused on the impact of exchange rate volatility on bilateral trade.

Wei [20] estimated a panel of 63 countries and find that exchange rate volatility has a significant negative impact on bilateral trade for country pairs with large potential trade. Rose [21] using a gravity model with a sample of 186 countries finds a negative impact of volatility on trade. Dell'Ariccia [22] examines the impact of exchange rate volatility of bilateral trade between the European Union and Switzerland over the period 1975-1994. The OLS results suggest that exchange-rate volatility has a small but significant negative impact on trade. The fixed and random effect modeling also gave the negative impact exchange volatility on trade, but the magnitude is relatively smaller. He also finds that by eliminating exchange rate volatility the volume of trade could increase by about $3.5 \%$ in 1994 which is consistent with Rose [21]. Tenreyro [23] studies a sample of 104 countries of both developing and developed countries from 1970 to 1997 using gravity model finds that volatility has an insignificant effect on bilateral trade.

\section{THE MODEL}

This study attempts to determine the relationship between the exchange rate volatility and the exports. In order to avoid misspecification, we also include the real exchange rate and real income (GDP) as other independent variables. Following Ekanayake, Thaver \& Plante [24], we specify the model in $\log$ form as:

$$
X_{i t}=\beta_{o i}+\beta_{1} Y_{i t}+\beta_{2} V_{i t}+\beta_{3} R E R_{i t}+\varepsilon_{i t}
$$

where $i$ denotes the original 5-ASEAN member nations comprising of Indonesia, Malaysia, the Philippine, Singapore, and Thailand; $X$ represents ASEAN exports to China, $Y$ is the GDP as a proxy of China's income, $V$ is the exchange rate volatility, $R E R$ is the real exchange rate, $i=1,2,3,4,5, t$ is time and $\varepsilon$ is the residual term. We postulate that $\beta_{1}$ is positive, as higher China's income will increase ASEAN exports to China; $\beta_{2}$ should be negative since an increase in exchange rate volatility reduces ASEAN exports to China, and $\beta_{3}$ should be positive as a depreciation of ASEAN member nations currencies against China's Yuan may lead to higher ASEAN exports to China.

\section{Sources of Data and Definition of Variables}

This study employs annual panel data of original ASEAN five member nations exports to China from 1992 to 2011 . The 
sources of data include the Direction of Trade Statistics (DOTs) of International Monetary Fund, OECD statistics, ASEAN statistics and World Development Indicators (WDI) by the World Bank. The dependent variable is the exports of each original 5-ASEAN member countries to China. The bilateral nominal exchange rate is measured as Yuan per unit of each ASEAN member nation's currency. Each of these bilateral nominal exchange rates are converted to the bilateral real exchange rates by multiplying with the CPI of China relative to CPI of each ASEAN member nation written as

$$
R E R_{i t}=e_{i t} \frac{C P I_{t}^{c}}{C P I_{i t}^{a n}}
$$

where $R E R$ is the real exchange, $e$ is the nominal exchange rate, $C P I^{C}$ and $C P I^{a n}$ are the consumer price indices of China and each of the ASEAN nations respectively, $t$ is time, and $i=$ $1,2,3,4,5$. The exchange rate volatility refers to the amount of uncertainty or risk about the size of changes in the bilateral nominal exchange rates. A higher volatility means that exchange rate can potentially be spread out over a larger range of values. A lower volatility means that exchange rate does not fluctuate dramatically, but changes in value at a steady pace over a period of time. In this study the exchange rate volatility is measured by the moving average of the standard deviation of the nominal exchange rate as used by a number of scholars such as Chowdhury [25], Klein [26], and Koray \& Lastrapes [27] given by:

$$
V_{i t}\left\{\frac{1}{m} \sum_{i=1}^{m}\left[\left(e_{i t+j-1}-e_{i t+j-2}\right)^{2}\right]^{1 / 2}\right\}
$$

where $m$ is the number of periods and $e$ refers to nominal exchange rate, $i=1,2,3,4,5$. In our study, $m=3$.

\section{Estimation Methods}

Since we are using panel data, the least squares estimation may be inappropriate as the errors are likely to be correlated across time and across-section units. But the least squares estimators are still unbiased, consistent, and asymptotically normally distributed but not efficient. The most appropriate technique of estimation is the Generalized Least Squares (GLS) method. To avoid bias in the estimates due to possible endogeneity of the repressors, we then use the generalized method of moments (GMM) technique estimation on the GLS transformed data using the lagged dependent and independent variables as instruments. Before the GMM technique is applied, we test for the existence of unit root in the panel data series.

\section{RESULTS AND DISCUSSION}

The results of panel unit roots using the panel unit root test proposed by Levin, Lin and Chu [28] (not reported here) indicate that the null hypothesis of unit root is rejected at $10 \%$ level of significance; thus all the variables are stationary in level.

Table I presents the summary of the panel least square estimation. The results suggest that both of the exchange rate volatility and GDP could significantly explain the variation in exports at one percent level with correct signs. Specifically, a one percent increase in volatility of the exchange rate reduces exports by 0.09 percent which is very inelastic; a one percent increase in China's GDP results in 1.94 percent in ASEAN exports to China which is relatively elastic. The real exchange rate has no impact on exports. But since we employ panel data, therefore the residuals are heteroskedastic and contemporaneously correlated As a result the estimated standard errors of OLS coefficients will be biased. We then estimate the model by the generalized method of moments (GMM) technique using the lags of the variables in the model as instruments.

TABLE I: RESULTS OF OLS

\begin{tabular}{lcccc}
\hline \multicolumn{5}{l}{ VariableCoefficientStd. Errort-Statistic Probability } \\
\hline$C$ & -38.92 & 1.40 & -27.71 & 0.0000 \\
$V$ & -0.09 & 0.02 & $-5.12 *$ & 0.0000 \\
$Y$ & 1.94 & 0.05 & $36.94 *$ & 0.0000 \\
$R E R$ & -0.19 & 0.12 & -1.62 & 0.1097 \\
\hline Notes: * significant at 1\% level, $C$ is the intercept. \\
\multicolumn{7}{c}{ TABLE II: RESULTS OF GMM } \\
\hline VariableCoefficientStd. Errort-StatisticProbability \\
\hline$C$ & -38.93 & 2.27 & -17.14 & 0.0000 \\
$V O L$ & -0.21 & 0.03 & $-7.82 *$ & 0.0000 \\
$G D P$ & 1.86 & 0.09 & $20.69 *$ & 0.0000 \\
$R E R$ & 1.12 & 0.27 & $4.21 *$ & 0.0001 \\
\hline Note: & $*$ significant at $1 \%$ level, $C$ is intercept.
\end{tabular}

Table II shows the results of the panel Generalized Method of Moments (GMM) estimation. All the variables indicate the correct signs and significant at 1 percent level the results support the hypothesis that the exchange rate volatility negatively affects export volume. The elasticity of exports with respect to exchange rate volatility is about 0.21 , suggesting that if volatility goes up by 1 percent, the export volume goes down by about 0.21 percent. The coefficient of GDP is about 1.86 implying if GDP increase by 1 percent, the exports increase by 1.86 percent. The real exchange rate is significant at 1 percent level; if real exchange rate increases by 1 percent, exports will increase by 1.12 percent.

\section{CONCLUSION}

The study examines the impact of exchange rate volatility, real GDP of China, and real bilateral exchange rates of ASEAN member nations against Yuan on the bilateral exports of ASEAN member countries to China by employing the generalized method of moments (GMM). We use panel data of 5 original ASEAN member nations: Malaysia, Singapore, Indonesia, the Philippine, and Thailand. The unit root tests indicate that there are no unit roots, and thus all the variables are stationary in level. The GMM results show that all the coefficients of the regressors have the expected signs and are statistically significant at the $1 \%$ level implying that exchange rate volatility, real bilateral exchange rates, and China's real GDP could significantly affect the bilateral exports of ASEAN countries to China. Specifically, the effect of exchange rate volatility on exports is inelastic; if exchange rate volatility goes up by 1 percent, the exports fall by about 0.21 percent. The effects of ASEAN real bilateral 
exchange rates and China's real GDP on ASEAN bilateral exports to China are elastic. When real bilateral exchange rates depreciate by 1 percent, exports will increase by 1.12 percent and when China's real GDP increases by 1 percent, the bilateral exports of ASEAN to China increase by 1.86 percent. The findings suggest that the ASEAN member nations should maintain the stability of their bilateral exchange rates with Chinese Yuan as a means to encourage their exports to China. The results also indicate that ASEAN exports to China is vulnerable to the performance of China's economy; if China's economy is not performing well it will adversely affect ASEAN exports to China.

\section{REFERENCES}

[1] E. Prasad, K. Rogoff, S. Wei, and M. A. Kose, "Effects of financial globalization on developing countries: some empirical evidence," IMF Occasional Paper, no. 220, 2003.

[2] G. Cho, I. Sheldon, and S. McCorriston, "Exchange rate uncertainty and agricultural trade," American Journal of Agricultural Economics, vol. 84, pp. 931-942, 2002.

[3] P. Krugman, "Exchange rate instability," The Lionel Robbins Lectures, Cambridge, The Massachusetts Institute of Technology Press, 1989.

[4] J. M. Viaene and C. G. de Vries, "International trade and exchange rate volatility," European Economic Review, vol. 36, pp. 1311-21, 1992.

[5] K. Grier and A. D. Smallwood, "Uncertainty and export performance: evidence from 18 countries," Journal of Money, Credit and Banking, vol. 39, no. 4, pp. 965-979, 2007.

[6] P. Aghion and P. Howitt, "International trade and growth," in Understanding Economic Growth, P. Aghion and P. Howitt Ed., MIT Press, 2007.

[7] P. B. Clark, "Uncertainty, exchange risk, and the level of international trade," Western Economic Journal, vol. 11, pp. 302-13, 1973.

[8] W. Ethier, "International trade and the forward exchange market," American Economic Review, vol. 63, no. 3, pp. 494-503, 1973.

[9] M. Kawai and I. Zilcha, "International trade with forward-futures markets under exchange rate and price uncertainty," Journal of International Economics, vol. 20, pp. 83-98, 1986.

[10] P. de Grauwe, "Exchange rate variability and the slowdown in growth of international trade," IMF Staff Papers, vol. 35, pp. 63-84, 1988.

[11] G. Franke, "Exchange rate volatility and international trading strategy," Journal of International Money and Finance, no. 2, pp. 292-307, 1991.

[12] P. Sercu and C. Vanhulle, "Exchange rate volatility, international trade, and the value of exporting firm," Journal of Banking and Finance, vol. 16, no. 1, pp. 152-182, 1992.

[13] M. J. Bailey, G. S. Tavlas, and M. Ulan, "Exchange-rate variability and trade performance: evidence for the big seven industrial countries," Weltwirtschaftliches-Archiv, vol. 122, pp. 466-77, 1986.

[14] S. Holly, "Exchange rate uncertainty and export performance: supply and demand effects," Scottish Journal of Political Economy, vol. 42, pp. 381-91, 1995.

[15] L. B. Smaghi, "Exchange rate variability and trade: why is it so difficult to find any empirical relationship?" Applied Economics, vol 23, pp. 927-35, 1991.
[16] J. C. Brada and J. A. Méndez, "Exchange rate risk, exchange rate regime and the volume of international trade," KYKLOS, vol. 41, pp. 263-80, 1988.

[17] J. A. Frankel and S. J Wei, "Trade blocs and currency blocs," Working Paper, National Bureau of Economic Research, Cambridge, no. 4335, 1993,

[18] C. A. Arize, T. Osang, and J. D. Slottje, "Exchange rate volatility and foreign trade: evidence from Thirteen LDCs," Journal of Business and Economic Statistics, vol. 18, no. 1, pp. 10-17, 2000

[19] M. Doganlar, "Estimating the impact of exchange rate volatility on export: evidence from Asian countries," Applied Economics Letters, vol. 9, pp. 859-863, 2000.

[20] S. J. Wei, "Currency hedging and goods trade," European Economic Review, vol. 43, pp. 1371-1394, 1999.

[21] A. Rose, "One money, one market: estimating the effect of common currency on trade," Economic Policy, vol. 30, pp. 7-45, 2000

[22] G. D. Ariccia, "Exchange rate fluctuations and trade flows: evidence from the European union," IMF Staff Papers, vol. 46, no. 3, pp. 315-334, 1999

[23] S. Tenreyro, "On the trade impact of nominal exchange rate volatility," Federal Reserve Bank of Boston, unpublished, 2004.

[24] E. M. Ekanayake, R. Thaver, and D. Plantel, "The effects of exchange rate volatility on South Africa's trade with the European union," The International Journal of Business and Finance Research, vol. 6, no. 3 , pp. 13-26, 2012.

[25] A. R. Chowdhury, "Does exchange rate volatility depress trade flows? Evidence from error correction models," Review of Economics and Statistics, vol. 76, pp. 700-06, 1993.

[26] M. W. Klein, "Sectoral effects of exchange rate volatility on the US Exports," Journal of International Money and Finance, vol. 9, pp. 299-308, 1990

[27] F. Koray and W. D. Lastrapes, "Real exchange rate volatility and U.S Bilateral Trade: a VAR approach," Review of Economics and Statistics, vol. 7, pp. 708-712, 1989.

[28] A. Levin, C. F. Lin, and C. Chu, "Unit root tests in panel data Asymptotic and finite-sample properties," Journal of Econometrics, vol. 108, no. 1, pp. 1-24, 2002.

Mohammed B. Yusoff obtained B.S. degree from Louisiana State University, Baton Rouge, Louisiana, USA in 1971. In the same year he pursued his graduate studies at Iowa State University, Ames, Iowa and received his PhD in economics in 1977. He is currently a professor of economics, International Islamic University Malaysia, Kuala Lumpur, Malaysia. His research interests are in the areas of international trade and finance, Islamic economics, Islamic banking and finance, and applied macroeconomics. Professor Yusoff was a visiting Fulbright scholar at Iowa State University from 1985-86. In 1995 he was awarded the Tun Razak professorial chair in South-east Asian Studies for two years at Ohio University, Athens, Ohio.

Ahmed Sabit received his bachelor degree in economics from the University of Dhaka, Bangladesh in 2008. He then pursued his graduate studies in International Islamic University Malaysia and graduated with a master degree in economics in July 2013. He is currently pursuing the PH.D. program in economics at Texas Tech University, Texas, USA. His research interests are in the areas of monetary economics, macroeconomics, fiscal policy and international trade and finance. 